\title{
Note on Abbreviations, Dates, and Pronunciation
}

The following abbreviations or short citations are used throughout this book:

Azumaasobiuta "Songs for the Eastern Dances," numbered as in Kodai Kayöshü, ed. Y. Tsuchihashi and J. Konishi, Tokyo, 1957.

FGS Fügash $\bar{u}, \mathrm{I}$ th imperial anthology, ca. 1345 .

GSIS Goshüish $\bar{u}, 4^{\text {th }}$ imperial anthology, 1086.

GSRJ Gunsho Ruijū, 30 vols., Tokyo, 1928-34.

GSS

GYS Gosenshü, 2nd imperial anthology, ca. 951.

Kagura Gyokuyöshü, i4th imperial anthology, ca. 1313. Shinto ceremonial songs, numbered as in Tsuchi$K K S$ hashi and Konishi, Kodai Kayōshü.

Kojiki Kokinshü, Ist imperial anthology, ca. 905. An early chronicle (712) containing songs numbered as in Tsuchihashi and Konishi, Kodai Kayōshü.

K. Taikei Köchū Kokka Taikei, 28 vols., Tokyo, 1927-31. KYS Kin'yöshü, 5th imperial anthology, ca. I127. Monogatari Poems from tales, as numbered in the Monogatari section of Kokka Taikan (see paragraph immediately following).

MYS Man'yosh $\bar{u}$, the great early collection of poetry, ca. 760 .

Nihongi An early chronicle (720) containing songs numbered as in Tsuchihashi and Konishi, Kodai Kayōshü. 
Nikki

$N K G T$

SCSS

SIS

$S K K S$

$S Z S$

ZGSRJ
Poems from diaries, as numbered in the Nikki section of Kokka Taikan.

Nihon Kagaku Taikei, ed. N. Sasaki, 6 vols., Tokyo, 1935, and reprinted.

Shinchokusensh $\bar{u}$, gth imperial anthology, ca. I234.

Shüishū, 3rd imperial anthology, ?990-1005.

Shinkokinshü, 8th imperial anthology, ca. 1206. Senzaish $\bar{u}, 7$ th imperial anthology, ca. I1 88.

Zoku Gunsho Ruijū, 71 vols., Tokyo, 1923-30.

The imperial anthologies, the Man'yōsh $\bar{u}$, and poems from the tales (monogatari) and diaries (nikki) will be found numbered in Kokka Taikan, ed. D. Matsushita and F. Watanabe, 2 vols., Tokyo, 1903, and often reprinted.

Citations of poems in the text refer to anthology or collection, to book or scroll number where appropriate, and to the number of the poem in the collection. "MYS, I: I," therefore, refers to the first poem in the first book of the Man'yöshü. Citations of poems in Gunsho Ruijü, Köchü Kokka Taikei, and Zoku Gunsho Ruijü refer to volume and page number (e.g., K. Taikei, XI, 98).

Even when not so indicated, dates are approximate. The dates of poets are given on first appearance and in the Index.

The poets are identified by their clan names and their given names or styles: e.g., Kakinomoto Hitomaro, Fujiwara Teika. They are later referred to by given names or styles: e.g., Hitomaro, Teika. Ranks and attributed appellations (i.e., acquired from a relative or from service) are given only for royalty, where other names are unknown, or where necessary to avoid confusion.

Transliterations of names or texts of poems have been normalized, where different, into modern equivalents.

Classical Japanese is constituted of lightly stressed syllables made up of a consonant and a vowel, a vowel, or $n$. Long vowels (e.g., $\bar{o})$ are counted as two syllables for prosodic purposes. The vowels 
ABBREVIATIONS, DATES, PRONUNCIATION

are "pure" or "simple," as in Spanish or Italian. The consonants are pronounced very much as in English, except for $r$, which involves touching the forepart of the roof of the mouth lightly with the tongue to produce a sound combining some features of $l$ and $d$. Pronouncing Japanese names or phrases with "pure" vowels, English consonants, and little stress will approximate the sound of the original.

For further discussion of these matters, and for a bibliography of Japanese sources and Western translations and criticism, see Robert H. Brower and Earl Miner, Japanese Court Poetry (Stanford, $196 \mathrm{r})$, pp. xv, xvi, 489-502. 

An Introduction to Japanese Court Poetry 
